\title{
Assessment of respiratory dust exposure and lung functions among workers in textile mill (Thamine), Myanmar: a cross- sectional study
}

Thet Wai Oo ${ }^{1} \mathbb{D}$, Mya Thandar ${ }^{2}$, Ye Minn Htun ${ }^{3^{*}}$ (D) Pa Pa Soe ${ }^{4}$, Thant Zaw Lwin ${ }^{5}$, Kyaw Myo Tun ${ }^{5}$ (i) and Zaw Myo Han ${ }^{6}$

\begin{abstract}
Background: Airborne dusts are being potentially harmful for workers in occupational environment. Exposure to respirable dust is the most important concern in textile workers for the widespread of occupational lung diseases, especially more serious in developing countries. The aim of the study was to assess the respirable dust exposure and associated factors of lung functions among textile workers.

Methods: A cross-sectional study was carried out at a textile mill (Thamine), Yangon Region, from April to December, 2018 and a total of 207 textile workers were randomly selected by using a multistage sampling procedure. Data were collected by using a structured questionnaire for respiratory symptoms, an air sampling pump for assessment of respirable dust exposure, and a spirometer for testing the lung functions. Logistic regression analysis was performed to assess the associated factors of lung functions. Odds ratios with a 95\% confidence interval were computed for strength of associations at the significance level of $a \leq 0.05$.
\end{abstract}

Results: The mean ( \pm standard deviation, SD) respirable dust exposure was $3.3 \mathrm{mg} / \mathrm{m}^{3}( \pm 0.69)$ and the prevalence of increased respirable dust exposure $\left(>3 \mathrm{mg} / \mathrm{m}^{3}\right.$ ) was $50.7 \%$. The level of respirable dust exposure was highest in the textile workers involving at twisting department. The means ( \pm SD) spirometry values were FVC $82.8 \%( \pm 17.8)$, $\mathrm{FEV}_{1}$ 83.6\% ( \pm 18.5 ), and $\mathrm{FEV}_{1} / \mathrm{FVC} 0.9( \pm 0.1)$. Overall magnitude of reduced lung functions was $40.1 \%$, and the prevalence of reduced FVC, FEV 1 , and $\mathrm{FEV}_{1} / \mathrm{FVC}$ were 36.7, 34.3 and 3.9\% respectively. The current working at twisting department, $>5$ years of service duration, respiratory symptoms and increased respirable dust exposure were associated with reduction in FVC and $\mathrm{FEV}_{1}$.

\footnotetext{
* Correspondence: dryeminnhtun85@gmail.com

${ }^{3}$ Department of Prevention and Research Development of Hepatitis, AIDS and Other Viral Diseases, Health and Disease Control Unit, Nay Pyi Taw, Myanmar

Full list of author information is available at the end of the article
}

(c) The Author(s). 2021 Open Access This article is licensed under a Creative Commons Attribution 4.0 International License, which permits use, sharing, adaptation, distribution and reproduction in any medium or format, as long as you give appropriate credit to the original author(s) and the source, provide a link to the Creative Commons licence, and indicate if changes were made. The images or other third party material in this article are included in the article's Creative Commons licence, unless indicated otherwise in a credit line to the material. If material is not included in the article's Creative Commons licence and your intended use is not permitted by statutory regulation or exceeds the permitted use, you will need to obtain permission directly from the copyright holder. To view a copy of this licence, visit http://creativecommons.org/licenses/by/4.0/. The Creative Commons Public Domain Dedication waiver (http://creativecommons.org/publicdomain/zero/1.0/) applies to the data made available in this article, unless otherwise stated in a credit line to the data. 


\begin{abstract}
(Continued from previous page)
Conclusions: The current working department, service duration, respiratory symptoms and exposure to respirable dust were predictors of lung functions in textile workers. An adequate ventilation, good work practices, hygienic workplace, safety and health training regarding potential health effects, and periodically assessment of lung functions are the critical elements for control of respirable dust exposure and reduction of occupational lung diseases.
\end{abstract}

Keywords: Dust exposure, Lung functions, Respiratory symptoms, Service duration, Textile worker

\section{Background}

Occupational lung disease is a major concern and it has been listed as one of the priority problems in occupational health $[1,2]$. In developing countries, workers are important as tools in production, and their health is at risk due to exposure to occupational hazards [2]. The textile industry is associated with a number of environmental problems such as water pollution, soil pollution, noise pollution, and air or dust pollution. Among these different textile pollutions, cotton dust pollution is the most important in terms of health effects on textile workers [3]. Dust are solid particles with a range in size from below 1 micron $(\mu \mathrm{m})$ up to at least $100 \mu \mathrm{m}$. They may be or become airborne depending on their origin, physical characteristics, and ambient conditions [4].

The respirable dust is the fraction of the dust reaching the alveolar region of the lungs and it can penetrate beyond the terminal bronchioles to the gas exchange region of the lungs. Cotton dust is the dust present in the air during the handling or processing of cotton, which may contain a mixture of substances including groundup plant matter, bacteria, fungi, soil, pesticides, and other contaminants [5]. Inhalation of the dust depends on its aerodynamic diameter, the velocity of the surrounding air, and the persons' breathing rate. The small aerodynamic diameter has a greater chance of deep penetration into the respiratory tract, and dust with an aerodynamic diameter $>10 \mu \mathrm{m}$ is easy to reach the gasexchange region of the lung [4].

A large amount of dust was generated in different areas of the weaving section in the textile mill such as ginning, carding, and spinning operations [6]. The spinning section might be exposed to cotton dust more than the other sections. The textile workers were exposed to heavy dust concentration in the first step of processing [7]. The small dust particles entered into the alveoli of the lungs through inhalation. The capacity of retaining oxygen could be reduced by the accumulation of dust in the lymph causing damage to the alveoli [8]. The initial pulmonary responses to the dust might be characterized by reversible respiratory symptoms and deterioration in lung functions [9].

Exposure to occupational dust is implicated in the etiology of several occupational respiratory diseases with considerable socio-sanitary consequences [10]. The textile workers exposed to respiratory dust might cause a variety of different respiratory health problems including byssinosis, chronic obstructive pulmonary disease, and respiratory irritation $[11,12]$. Cough, expectoration, and chest tightness were more prevalent in spinning and weaving workers [13]. The typical symptoms caused by exposure to respiratory dust were chronic cough with or without phlegm, dyspnea, wheezing, nasal stuffiness, and chest tightness [13-15]. The extent of chronic functional losses in textile workers was apparently affected by the consistency of reporting respiratory symptoms. It could be a stronger relationship between chronic respiratory diseases and spontaneous deteriorations in lung functions $[15,16]$.

In every industry, a safe workplace is crucial to achieving the highest productivity level. Therefore, the promotion and protection of a safe workplace is the complementary element of industrial development [17]. Finding and fixing workplace hazards before illness were the major concerns for safety and health at the workplace. Primary preventive interventions are important to reduce dust exposure in the workplace and remain vital for the elimination of the occupational lung disease burden [18]. Although the major improvements in dust control have occurred in many textile industries, a considerable proportion of textile workers are at risk of developing lung diseases, even at very low dust concentration in the workplace.

The studies conducted in Taiwan and Pakistan found that increased cotton dust concentration led to a reduction of lung functions in textile workers $[8$, 19]. In Myanmar, textile manufacturing is a laborintensive industry and pivotal place in the economy. It represents one of the largest groups of manufacturing industries in terms of the value of production and source of direct employment to the people. However, the respiratory problems due to dust exposure is not well known and there is a limited scientific evidence for showing these kind of health issue in Myanmar. Therefore, the aim of the study was to assess respirable dust exposure and associated factors of lung functions among textile workers. 


\section{Methods}

\section{Study design and setting}

A cross-sectional study was carried out among workers in a textile mill (Thamine), Yangon Region, Myanmar, between April and December 2018. There were 12 textile processing sections in this textile mill. The workers were working 8 -h of work shift every day and wearing reusable cotton cloth face masks during working hours. As a ventilation condition, the working departments were equipped with general ventilation by installing the outlets at ceiling or exhaust fans, and local exhaust ventilation system.

\section{Study population}

The study population was the textile workers who were working in six departments (weaving, knitting, opening, carding, spinning, and twisting) of the weaving section. Of these, the workers who did not give informed consent, and those who had heart diseases, tuberculosis, asthma and other respiratory diseases were excluded. The interview survey and lung function test were performed to all participants, and assessment of respiratory dust exposure was done at the personal breathing zones of the textile workers in each department. Smoking status was defined as a history of smoking occasionally or currently (cigarettes or cigars), or stopped smoking less than 6 months from the time of the study.

\section{Sampling technique and procedure}

A single population proportion formula was used to calculate the sample size of the study. By using the prevalence of abnormal $\mathrm{FEV}_{1}(p=0.16)$ from the study conducted in Greece [12], with an assumption of $95 \%$ confidence interval (CI), 5\% margin of error, and $10 \%$ non-response rate, the final sample size was 207. A multistage sampling technique was used for this study. The weaving section was initially selected by purposive sampling. The total number of workers in six departments of the weaving section was 438. Secondly, the workers were selected using stratified random sampling, assuming that the workers in different departments would exhibit different level of exposure to respirable dust. Each department was taken as a stratum. The workers were allocated to each stratum proportionally to represent for their departments and selected by simple random sampling.

\section{Data collection procedures and data quality control Interviews}

A face-to-face interview was done by two interviewers using structured questionnaires. The questionnaire was developed by related literature (Additional file 1) and following an approved survey questionnaire of the Committee on Environmental and Occupational Health,
British Medical Research Council [20]. The main contents of the questionnaire were background characteristics of participants (sex, age, educational status, current department, duration of service in current department, and smoking status) and the respiratory symptoms (cough, phlegm, cough with phlegm, rhinitis, wheezing, breathlessness, and chest illness). The initial version of the questionnaire was translated into the Burmese language and back-translated into English to verify accuracy. For the content validity, the questionnaire was pretested on 5\% textile workers from Htet Aung garment factory that fulfilled the inclusion criteria. The inputs from the pretest were used to modify the questionnaire in more suitable contexts in order to generate intended data. The homogeneity of the questionnaire was fair to strong with high Cronbach $\alpha$ ranging from 0.70 to 0.83 . The interview was conducted in a private setting and the consistency was checked before, during, and after entering the data.

\section{Air sampling pump}

An air sampling pump (AirChek 3000 Deluxe model 210-3311, SKC Limited, United Kingdom) was used for the assessment of respirable dust exposure in each department. It was performed by an occupational hygienist and placed at the personal breathing zones of the workers who were working with the cotton base materials. The two respirable dust samples were collected from each department. Samples were collected at a flow rate of $2.2 \mathrm{l} / \mathrm{min}$ during an 8 -h work shift. All samples were collected on a Whatman glass microfiber filters having a $2.5 \mathrm{~cm}$ diameter to fit the sampling head. The weighting of the filter was on a calibrated analytical balance before and after sample collection, performed by a hygienist at the Occupational and Environmental Health Laboratory, Yangon.

\section{Spirometry}

A spirometer (Vitalograph In2itive model 2120, version 1.05, Vitalograph Limited, United Kingdom) was used for determining lung functions of the textile workers. Before testing, calibration of the spirometry was performed with the $3 \mathrm{~L}$ precision syringe. Firstly, Vitalograph compact flow head connected to the $3 \mathrm{~L}$ syringe and accuracy check monitor. The plunger was pulled out as far as possible before injecting the air and pumped the plunger into the syringe to inject the air. The results were automatically displayed and the system accuracy was checked again if the results were not within the acceptable range of 2.9-3.11 L.

After the accuracy check and explained the procedure to the participants, the lung function testing was performed by an occupational hygienist. The mouse piece was cleaned with antiseptic agents. In order to achieve 
the correct measurement of spirometry, the occupational hygienist made sure that the posturing of the participants was done by sitting upright, touching feet flat on the floor with legs uncrossed, losing tight-fitting clothing, leaving dentures in the mouth normally, and using a chair with arms. Before performing the procedure, the participants had instructed to practice deep inspiration and complete forceful expiration. The highest values for forced vital capacity (FVC) and forced expiratory volume in the first second $\left(\mathrm{FEV}_{1}\right)$ after three acceptable maneuvers were used in subsequent analysis.

\section{Measurement of variables}

A participant presenting at least one symptom was considered as the symptomatic person in this study. The duration of service in the current department was the total number of working years in the current department of the weaving section. If a decimal was greater than 6 (months), the length was counted as 1 (year) and equal 0 if less than 6 (months). The concentration of respirable dust exposure was classified at $>3 \mathrm{mg} / \mathrm{m}^{3}$ of $8 \mathrm{~h}$ mean dust concentration as increase exposure, and $\leq 3 \mathrm{mg} / \mathrm{m}^{3}$ as acceptable exposure [21]. The concentration of respirable dust exposed to workers was calculated according to the following equation:

$$
\text { Concentration }(\mathrm{mg} / \mathrm{m} 3)=\frac{\text { Final weight }(\mathrm{mg})-\text { Initial weight }(\mathrm{mg})}{\text { Time }(\mathrm{min}) \times \text { flow rate }(\text { litre } / \mathrm{min})} \times 1,000
$$

The lung functions of the participants were measured by a hygienist and expressed as percent prediction. FVC was defined as the total expiratory volume from one time of a maximally forced expiration maneuver. $\mathrm{FEV}_{1}$ was defined as expiratory volume that has been exhaled at the end of the first second of a maximally forced expiration maneuver. $\mathrm{FEV}_{1} / \mathrm{FVC}$ was defined as the ratio of $\mathrm{FEV}_{1}$ and $\mathrm{FVC}$ which was expressed by the American Thoracic Society/Europe Respiratory Society Best (ATS/ ERS Best), and it provided the identification of obstructive or restrictive impairment. The normal lung function was defined as $\geq 80 \%$ of predicted $\mathrm{FVC}, \geq 80 \%$ of predicted $\mathrm{FEV}_{1}$, and $\geq 0.7$ of $\mathrm{FEV}_{1} / \mathrm{FVC}$. The abnormal lung function was categorized as restrictive and obstructive impairments. Restrictive impairment was characterized by a normal $\mathrm{FEV}_{1} / \mathrm{FVC}$ with reduced $\mathrm{FVC}$ and normal or reduction in $\mathrm{FEV}_{1}$. The obstructive impairment was characterized by a reduction in $\mathrm{FEV}_{1} / \mathrm{FVC}$ with reduced or normal FVC, and reduced $\mathrm{FEV}_{1}[22,23]$.

\section{Data processing and analysis}

The data were coded, entered into a Microsoft Excel sheet (version 2016), and checked for errors. Data analysis was performed by using the International Business Machines Corporation-Statistical Package for Social Sciences program version 23 . The mean and standard
Table 1 Background characteristics of textile workers

\begin{tabular}{|c|c|}
\hline Variables & Frequency (\%) \\
\hline \multicolumn{2}{|l|}{ Sex } \\
\hline Male & $19(9.2)$ \\
\hline Female & $188(90.8)$ \\
\hline \multicolumn{2}{|l|}{ Age (year) } \\
\hline$\leq 30$ & $61(29.5)$ \\
\hline $31-40$ & $52(25.1)$ \\
\hline $41-50$ & $56(27.1)$ \\
\hline$>50$ & $38(18.4)$ \\
\hline \multicolumn{2}{|c|}{ Mean \pm SD $(38.8 \pm 11.2)$ years, Minimum 18 years, Maximum 60 years } \\
\hline \multicolumn{2}{|l|}{ Educational status } \\
\hline Read and write & $3(1.4)$ \\
\hline Primary school education & $18(8.7)$ \\
\hline Middle school education & $62(30.0)$ \\
\hline High school education & $93(44.9)$ \\
\hline College or University & $11(5.3)$ \\
\hline Graduate and above & $20(9.7)$ \\
\hline \multicolumn{2}{|l|}{ Current department } \\
\hline Weaving & $78(37.7)$ \\
\hline Knitting & $24(11.6)$ \\
\hline Carding & $13(6.3)$ \\
\hline Spinning & $40(19.3)$ \\
\hline Twisting & $40(19.3)$ \\
\hline Opening & $12(5.8)$ \\
\hline \multicolumn{2}{|c|}{ Duration of service in current department (year) } \\
\hline$\leq 5$ & $54(26.1)$ \\
\hline $6-10$ & $54(26.1)$ \\
\hline $11-15$ & $16(7.7)$ \\
\hline$>15$ & $83(40.1)$ \\
\hline \multicolumn{2}{|c|}{ Mean \pm SD $(13.4 \pm 10.6)$ years, Minimum 0.5 year, Maximum 39.0 years } \\
\hline \multicolumn{2}{|l|}{ Smoking status } \\
\hline No & $199(96.1)$ \\
\hline Yes & $8(3.9)$ \\
\hline
\end{tabular}

deviation (SD) were expressed for the result of a continuous variable, whereas frequency and percentage were used to display the result of the categorical variable. The normality of the continuous data was viewed by using the Kolmogorov-Smirnov test and the data distribution was normal. The differences between means of respirable dust concentration in six departments were calculated by using one-way analysis of variance with a postHoc Tukey HSD test. Bivariate logistic regression analysis was performed to identify the associated factors of dependent variable, reduced lung functions. The variables with significant association were identified on the 
basis of odd ratio (OR) with $95 \%$ confidence interval (CI) and $p$ value $\leq 0.05$.

\section{Results}

\section{Background characteristics of textile workers}

A total of 207 workers from six departments were selected in this study. As shown in Tables 1, 90.8\% were women and only $9.2 \%$ were men. The mean $( \pm$ SD) age was $38.8( \pm 11.2)$ years with a range of $18-60$ years and $29.5 \%$ of textile workers were age group of $\leq 30$ years. For educational level, $44.9 \%$ attained a high school education, and 9.7\% were graduate and above. Among the total, $37.7 \%$ were in the weaving department, each of $19.3 \%$ were involving in the spinning and twisting departments, respectively, and $5.8 \%$ were in opening department. The mean duration of service in the current department was 13.4 $(\mathrm{SD} \pm 10.6)$ years with a range of $0.5-39.0$ years and $40.1 \%$ had more than 15 years of service duration in the current department. Of all workers, $3.9 \%$ were smokers and $96.1 \%$ had no history of smoking.

Table 2 Prevalence of respiratory symptoms among textile workers

\begin{tabular}{ll}
\hline Respiratory symptoms & Frequency (\%) \\
\hline Respiratory symptoms & $98(47.3)$ \\
Absent & $109(52.7)$ \\
Present & \\
Cough & $189(91.3)$ \\
Absent & $18(8.7)$ \\
Present & \\
Phlegm & $163(78.7)$ \\
Absent & $44(21.3)$ \\
Present & \\
Cough with phlegm & $188(90.8)$ \\
Absent & $19(9.2)$ \\
Present & \\
Rhinitis & $174(84.1)$ \\
Absent & $33(15.9)$ \\
Present & \\
Wheezing & $186(89.9)$ \\
Absent & \\
Present & \\
Breathlessness & $10(4.8)$ \\
Absent & \\
Present & 136 (65.1) \\
Absent & \\
Present & \\
\hline
\end{tabular}

\section{Prevalence of respiratory symptoms among textile workers}

Table 2 showed the respiratory symptoms of textile workers. Among the total participants, 52.7\% had respiratory symptoms. As for specific respiratory symptoms, $8.7 \%$ reported cough, $21.3 \%$ phlegm, 9.2\% cough and phlegm, $15.9 \%$ rhinitis, $10.1 \%$ wheezing, $34.3 \%$ breathlessness and $4.8 \%$ chest illness.

\section{Respirable dust exposure and lung functions among textile workers}

As shown in Table 3, 50.7\% of textile workers exposed to $>3 \mathrm{mg} / \mathrm{m}^{3}$ of respirable dust exposure. The mean $( \pm$ $\mathrm{SD})$ respirable dust exposure was $3.3( \pm 0.7) \mathrm{mg} / \mathrm{m}^{3}$ with a range of $2.4-4.1 \mathrm{mg} / \mathrm{m}^{3}$. The respirable dust concentration in each department was shown in Fig. 1. The means $( \pm \mathrm{SD})$ respirable dust concentration were $2.7( \pm$ $0.1) \mathrm{mg} / \mathrm{m}^{3}$ in the weaving department, $2.4( \pm 0.1) \mathrm{mg} /$ $\mathrm{m}^{3}$ in the knitting department, $3.6( \pm 0.2) \mathrm{mg} / \mathrm{m}^{3}$ in the carding department, $4.0( \pm 0.2) \mathrm{mg} / \mathrm{m}^{3}$ in the spinning department, $4.1( \pm 0.1) \mathrm{mg} / \mathrm{m}^{3}$ in the twisting department and $3.8( \pm 0.3) \mathrm{mg} / \mathrm{m}^{3}$ in the opening department. The difference of means respirable dust exposure among six departments was statistically significant, $F(5,6)=$ 31.8 and $p<0.001$.

Concerning lung functions of textile workers, $40.1 \%$ had reduced lung functions, of which $90.4 \%$ had restrictive impairment and 9.6\% had obstructive impairment. The mean $( \pm$ SD) of FVC was $82.8 \%( \pm 17.8)$ with a range of $26-134$ and $36.7 \%$ of participants presented a reduction in FVC. The mean $\left( \pm\right.$ SD) of $\mathrm{FEV}_{1}$ was $83.6 \%$ $( \pm 18.5)$ with a range of $22-149$ and $34.3 \%$ of participants presented a reduction in $\mathrm{FEV}_{1}$. For the $\mathrm{FEV}_{1} / \mathrm{FVC}$, the mean $( \pm \mathrm{SD})$ was $0.9( \pm 0.1)$ with a range of $0.6-1.0$ and $3.9 \%$ of participants presented a reduction in it.

\section{Factors associated with lung functions among textile workers}

As shown in Table 4, the workers involved in twisting department $(\mathrm{OR}=3.00,95 \% \mathrm{CI}=1.35-6.66)$, those who had $6-10$ years of service duration $(\mathrm{OR}=4.60,95 \% \mathrm{CI}=1.83-$ $11.58)$, those who had $11-15$ years of service duration (OR $=$ 7.39, 95\% CI $=2.14-25.56)$, those who had $>15$ years of service duration $(\mathrm{OR}=4.19,95 \% \mathrm{CI}=1.76-9.98)$, those who were with respiratory symptoms $(\mathrm{OR}=4.12$, 95\% CI $=2.22$ 7.64), those who had increased exposure of respirable dust $(\mathrm{OR}=2.04,95 \% \mathrm{CI}=1.14-3.63)$ were significantly associated with reduction in FVC. Likewise, the workers involved in twisting department $(\mathrm{OR}=3.43,95 \% \mathrm{CI}=1.53-7.69)$, those who had $6-10$ years of service duration $(\mathrm{OR}=2.80,95 \% \mathrm{CI}=$ 1.16-6.73), those who had 11-15 years of service duration $(\mathrm{OR}=3.42,95 \% \mathrm{CI}=1.03-11.39)$, those who had $>15$ years of service duration $(\mathrm{OR}=2.90,95 \% \mathrm{CI}=1.29-6.56)$, those who were with respiratory symptoms $(\mathrm{OR}=2.82,95 \% \mathrm{CI}=$ 
Table 3 Respirable dust exposure and lung functions among textile workers

\begin{tabular}{|c|c|}
\hline Variables & $\begin{array}{l}\text { Frequency } \\
\text { (\%) }\end{array}$ \\
\hline \multicolumn{2}{|l|}{ Respirable dust exposure } \\
\hline Acceptable $\left(\leq 3 \mathrm{mg} / \mathrm{m}^{3}\right)$ & $102(49.3)$ \\
\hline Increased $\left(>3 \mathrm{mg} / \mathrm{m}^{3}\right)$ & $105(50.7)$ \\
\hline \multicolumn{2}{|c|}{ Mean \pm SD $(3.3 \pm 0.7)$, Minimum 2.4, Maximum 4.1} \\
\hline \multicolumn{2}{|l|}{ Lung functions } \\
\hline Normal & $124(59.9)$ \\
\hline Reduced & $83(40.1)$ \\
\hline Restrictive & $75(90.4)$ \\
\hline Obstructive & $8(9.6)$ \\
\hline \multicolumn{2}{|l|}{ FVC (\% prediction) } \\
\hline Normal ( $\geq 80 \%)$ & $131(63.3)$ \\
\hline Reduced (< 80\%) & $76(36.7)$ \\
\hline \multicolumn{2}{|c|}{ Mean \pm SD $(82.8 \pm 17.8)$, Minimum 26, Maximum 134} \\
\hline \multicolumn{2}{|l|}{$\mathrm{FEV}_{1}$ (\% prediction) } \\
\hline Normal ( $\geq 80 \%)$ & $136(65.7)$ \\
\hline Reduced (< 80\%) & $71(34.3)$ \\
\hline \multicolumn{2}{|c|}{$\begin{array}{l}\text { Mean } \pm \text { SD (83.6 } \pm 18.5) \text {, Minimum 22, Maximum } \\
149\end{array}$} \\
\hline \multicolumn{2}{|l|}{$\mathrm{FEV}_{1} / \mathrm{FVC}$} \\
\hline Normal $(\geq 0.7)$ & $199(96.1)$ \\
\hline Reduced $(<0.7)$ & $9(3.9)$ \\
\hline \multicolumn{2}{|c|}{ Mean \pm SD $(0.9 \pm 0.1)$, Minimum 0.6, Maximum 1.0} \\
\hline
\end{tabular}

1.54-5.17), those who had increased exposure of respirable dust $(\mathrm{OR}=1.83,95 \% \mathrm{CI}=1.02-3.29)$ were significantly associated with reduction in $\mathrm{FEV}_{1}$.

\section{Discussion}

This study has assessed the respirable dust exposure and associated factors of lung functions in textile workers. Almost all textile workers were female, and the malefemale ratio was 1:10 in this study. It was similar to the result of the study carried out in Thailand stated that the majority of participants were female [24], while the study conducted in Ethiopia reported that there was no difference in sex distribution [25]. It might be due to different study areas and the nature of employment which means that the textile industry is generally or traditionally viewed as suitable employment for female workers in Myanmar. The mean age of textile workers was 38.8 years and it was consistent with the studies done in Thailand [24] and Nigeria [26] reported that the means age of participants were 39.7 and 36.9 years, respectively. In this study, most of the textile workers had a high school education level, but other studies conducted in the same constitution of India [27] and Ethiopia [28] stated that most of the participants were up to high school and illiterate, respectively.

For the duration of service in the current department, most of the textile workers had more than 15 years of service duration. In contrast, a study conducted in India reported that most participants had more than 20 years of service duration [27] and, in an Ethiopia study, most of the participants were exposed to the dust in the current section for 20 to 30 years [25]. In reported respiratory symptoms, $52.7 \%$ of textile workers had at least

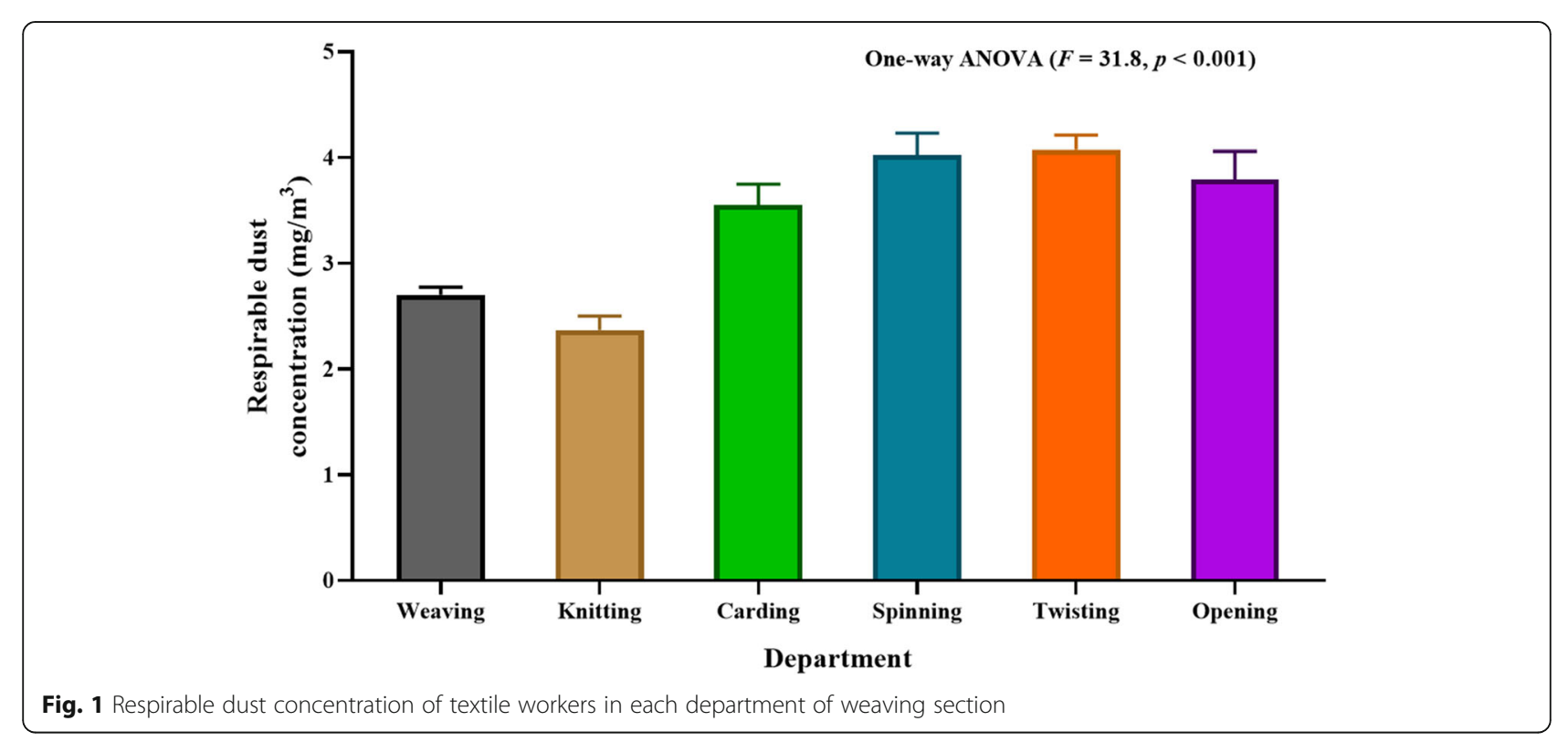


Table 4 Factors associated with lung functions among textile workers

\begin{tabular}{|c|c|c|c|c|c|c|c|}
\hline \multirow[t]{2}{*}{ Variables } & \multirow[t]{2}{*}{ Total } & \multirow{2}{*}{$\begin{array}{l}\text { FVC } \\
\text { Reduced } \\
\text { n (\%) }\end{array}$} & \multirow[b]{2}{*}{$\begin{array}{l}\text { OR } \\
(95 \% \mathrm{Cl})\end{array}$} & \multicolumn{2}{|l|}{$\mathrm{FEV}_{1}$} & \multicolumn{2}{|l|}{$\mathrm{FEV}_{1} / \mathrm{FVC}$} \\
\hline & & & & $\begin{array}{l}\text { Reduced } \\
\text { n (\%) }\end{array}$ & $\begin{array}{l}\text { OR } \\
(95 \% \mathrm{Cl})\end{array}$ & $\begin{array}{l}\text { Reduced } \\
\text { n (\%) }\end{array}$ & $\begin{array}{l}\text { OR } \\
(95 \% \mathrm{Cl})\end{array}$ \\
\hline \multicolumn{8}{|l|}{ Gender } \\
\hline Male & 19 & $6(31.6)$ & 1.00 & $6(31.6)$ & 1.00 & $2(10.5)$ & 1.00 \\
\hline Female & 188 & $70(37.2)$ & $\begin{array}{l}1.29 \\
(0.47-3.53)\end{array}$ & 65 (34.6) & $\begin{array}{l}1.15 \\
(0.42-3.15)\end{array}$ & $6(3.2)$ & $\begin{array}{l}0.28 \\
(0.05-1.48)\end{array}$ \\
\hline \multicolumn{8}{|l|}{ Age } \\
\hline$<40$ years & 109 & $35(32.1)$ & 1.00 & $34(31.2)$ & 1.00 & $3(2.8)$ & 1.00 \\
\hline$\geq 40$ years & 98 & $41(41.8)$ & $\begin{array}{l}1.52 \\
(0.86-2.68)\end{array}$ & $37(37.8)$ & $\begin{array}{l}1.34 \\
(0.75-2.38)\end{array}$ & $5(5.1)$ & $\begin{array}{l}1.90 \\
(0.44-8.17)\end{array}$ \\
\hline \multicolumn{8}{|l|}{ Educational level $^{a}$} \\
\hline$\geq$ High school education level & 124 & $41(33.1)$ & 1.00 & $39(31.5)$ & 1.00 & $4(3.2)$ & 1.00 \\
\hline$<$ High school education level & 83 & $35(42.2)$ & $\begin{array}{l}1.48 \\
(0.83-2.62)\end{array}$ & $32(38.6)$ & $\begin{array}{l}1.36 \\
(0.76-2.45)\end{array}$ & $4(4.8)$ & $\begin{array}{l}1.52 \\
(0.36-6.25)\end{array}$ \\
\hline \multicolumn{8}{|l|}{ Current department } \\
\hline Weaving & 78 & $21(26.9)$ & 1.00 & $19(24.4)$ & 1.00 & $3(3.8)$ & 1.00 \\
\hline Knitting & 24 & $8(33.3)$ & $\begin{array}{l}1.36 \\
(0.51-3.64)\end{array}$ & $9(37.5)$ & $\begin{array}{l}1.86 \\
(0.70-4.94)\end{array}$ & $1(4.2)$ & $\begin{array}{l}1.09 \\
(0.11-10.96)\end{array}$ \\
\hline Carding & 13 & $4(30.8)$ & $\begin{array}{l}1.21 \\
(0.34-4.34)\end{array}$ & $4(30.8)$ & $\begin{array}{l}1.38 \\
(0.38-4.99)\end{array}$ & $0(0.0)$ & 0.00 \\
\hline Spinning & 40 & $16(40.0)$ & $\begin{array}{l}1.81 \\
(0.81-4.05)\end{array}$ & $13(32.5)$ & $\begin{array}{l}1.49 \\
(0.65-3.46)\end{array}$ & $2(5.0)$ & $\begin{array}{l}1.32 \\
(0.21-8.21)\end{array}$ \\
\hline Twisting & 40 & $21(52.5)$ & $\begin{array}{l}3.00 \\
(1.35-6.66) * *\end{array}$ & $21(52.5)$ & $\begin{array}{l}3.43 \\
(1.53-7.69) * *\end{array}$ & $1(2.5)$ & $\begin{array}{l}0.64 \\
(0.06-6.37)\end{array}$ \\
\hline Opening & 12 & $6(50.0)$ & $\begin{array}{l}2.71 \\
(0.79-9.35)\end{array}$ & $5(41.7)$ & $\begin{array}{l}2.22 \\
(0.63-7.81)\end{array}$ & $1(8.3)$ & $\begin{array}{l}2.27 \\
(0.22-23.83)\end{array}$ \\
\hline \multicolumn{8}{|l|}{ Service duration } \\
\hline$\leq 5$ years & 54 & $8(14.8)$ & 1.00 & $10(18.5)$ & 1.00 & $0(0.0)$ & \\
\hline $6-10$ years & 54 & $24(44.4)$ & $\begin{array}{l}4.60 \\
(1.83-11.58) * * *\end{array}$ & $21(38.9)$ & $\begin{array}{l}2.80 \\
(1.16-6.73) *\end{array}$ & $3(5.6)$ & \\
\hline $11-15$ years & 16 & $9(56.3)$ & $\begin{array}{l}7.39 \\
(2.14-25.56) * *\end{array}$ & $7(43.8)$ & $\begin{array}{l}3.42 \\
(1.03-11.39) *\end{array}$ & $1(6.3)$ & \\
\hline$>15$ years & 83 & $35(42.2)$ & $\begin{array}{l}4.19 \\
(1.76-9.98)^{* * *}\end{array}$ & 33 (39.8) & $\begin{array}{l}2.90 \\
(1.29-6.56) * *\end{array}$ & $4(4.8)$ & \\
\hline \multicolumn{8}{|l|}{ Smoking status } \\
\hline No & 199 & $74(37.2)$ & 1.00 & 70 (35.2) & 1.00 & $8(4.0)$ & \\
\hline Yes & 8 & $2(25.0)$ & $\begin{array}{l}0.56 \\
(0.11-2.86)\end{array}$ & $1(12.5)$ & $\begin{array}{l}0.26 \\
(0.03-2.18)\end{array}$ & $0(0.0)$ & \\
\hline \multicolumn{8}{|l|}{ Respiratory symptoms } \\
\hline Absent & 98 & $20(20.4)$ & 1.00 & $22(22.4)$ & 1.00 & $5(5.1)$ & 1.00 \\
\hline Present & 109 & $56(51.4)$ & $\begin{array}{l}4.12 \\
(2.22-7.64) * * *\end{array}$ & $49(45.0)$ & $\begin{array}{l}2.82 \\
(1.54-5.17) * * *\end{array}$ & $3(2.8)$ & $\begin{array}{l}0.53 \\
(0.12-2.26)\end{array}$ \\
\hline \multicolumn{8}{|l|}{ Respirable dust exposure } \\
\hline Acceptable & 102 & $29(28.4)$ & 1.00 & $28(27.5)$ & 1.00 & $4(3.9)$ & 1.00 \\
\hline Increased & 105 & $47(44.8)$ & $\begin{array}{l}2.04 \\
(1.14-3.63) *\end{array}$ & $43(41.0)$ & $\begin{array}{l}1.83 \\
(1.02-3.29) *\end{array}$ & $4(3.8)$ & $\begin{array}{l}0.97 \\
(0.24-3.99)\end{array}$ \\
\hline
\end{tabular}

a Education level - categorized as $\geq$ high school education level (high school education, college/university, and graduate and above) and $<$ high school education level (read and write, primary school education, and middle school education)

${ }^{*} p<0.05,{ }^{* *} p<0.01,{ }^{* * *} p<0.001$ 
one respiratory symptom, and it was lower than the finding of a study done in Egypt showed that 59\% of participants had respiratory symptoms. However, it was higher than the findings of the same studies conducted in Taiwan [8] and Ethiopia [29] reported that and 39.7 and $47.8 \%$ of participants had respiratory symptoms respectively.

The occupational lung diseases were rapid outsourcing of textile industries due to the long exposure period in the workplace and poor control measures. The textile workers who were exposed to dust reported respiratory symptoms as a result of hypersensitive airways and an acute reduction in $\mathrm{FEV}_{1}$ [30]. Most of the acute respiratory symptoms due to dust exposure in textile workers were chest tightness, cough, and dyspnea [29]. In this study, breathlessness $34.3 \%$, and phlegm $21.3 \%$ were the commonest respiratory symptoms reported by the textile workers. The reported respiratory symptoms of textile workers in the same occupational setting varied substantially from different studies. In contrast with other findings, a study conducted in Thailand revealed that there was a high prevalence of chest tightness $64.6 \%$ and phlegm 59.1\% among the participants [10]. A Pakistan study stated that the wheezing 20\% and phlegm $20 \%$ were the most reported respiratory symptoms of textile workers [19].

In this study, the mean respirable dust concentration was $3.30 \mathrm{mg} / \mathrm{m}^{3}$, and $50.7 \%$ of textile workers were exposed to an increased level of respirable dust concentration. This finding was higher than the study done in Thailand showed that the mean respirable dust concentration was $0.53 \mathrm{mg} / \mathrm{m}^{3}$ in sewing workers [10]. It might be due to the fact that the textile workers in the weaving section exceeded occupational dust exposure. In this study, the mean respirable dust concentration in the twisting department was more than the other departments of the weaving section. In contrast, the carding department was an area of highest dust concentration in the studies done in Ethiopia [25, 31] and Taiwan [8]. Additionally, a similar study reported that the dust concentration was varied between the working departments and the level of dust concentration was higher in the cleaning department than in the spinning and weaving departments [28]. This inconsistency in the results might be, in part, due to the methodological variation, the difference in an industrial setting, and the handling and processing of cotton.

In this study, the prevalence of reduced lung functions, $40.1 \%$, among textile workers was higher compared with the other study done in Taiwan reported that $38.5 \%$ had reduced lung functions. Regarding spirometry patterns, $36.2 \%$ of textile workers had the restrictive pattern and it was lower than a similar study done in Nigeria found that the prevalence of restrictive pattern was $40.0 \%$ among textile workers [26]. There were $3.9 \%$ of an obstructive pattern among textile workers in this study, but conversely, the studies conducted in Zimbabwe [32] and Nigeria [26] reported that 27.8 and $10.0 \%$ of study participants had the obstructive pattern. The mean value of FVC, $82.82 \%$, was lower than the studies done in the same occupational setting at Thailand $106.0 \%$, Greece 90.6\%, and Pakistan 90.3\% [10, 12, 19]. The mean value of $\mathrm{FEV}_{1}, 83.64 \%$, was coincided with the result of a study conducted in Pakistan [19], however, it was lower than the studies done in Thailand $101.0 \%$, Iran $88.8 \%$, Turkey $96.2 \%$, and Greece 91.7\% [10, 12, 33, 34]. This inconsistency of results might be attributable to the usage of different types of spirometers in these studies.

As a current working department, respirable dust concentration was highest in the twisting department, and the textile workers who were working in this department were the more likely to reduce lung functions compared with those who were working in other departments. The various conditions such as the quality of the cotton, the production rate, the ventilation system, the processing method, and the method of dust sampling and analysis might affect the concentration of dust in the working environment [31]. The direct exposure to dust might contribute to reduced lung functions, and pulmonary diseases due to occupational exposure are mostly related to inhalation of dust and its deposition in the lungs [13].

The duration of service in the current department was associated with lung functions and the textile workers who were exposed to dust $>5$ years were more likely to reduce their lung functions than those who had $\leq 5$ years of service duration. This finding was also in line with the study conducted in India reported that cotton mill workers with $>5$ years of dust exposure were more likely to have spirometric abnormality [29]. Consequently, the textile workers with long service duration and chronic exposure to dust were at high risk of developing chronic respiratory health problems [35]. However, the studies conducted in the same constitutions of Egypt and Nigeria showed that there was no correlation between spirometric functions and duration of exposure to dust in the current section among cotton textile workers [13, 26]. It might be due to the variation of the working environment and concentration of dust exposure in workplaces.

The textile workers with respiratory symptoms had 3.64 times more likely to reduce respiratory function than those who had no respiratory symptoms. The result of the current study was in agreement with a study done in Nigeria showed that the textile workers with respiratory symptom had low $\mathrm{FEV}_{1}$ predicted value and a possibility of obstructive airway disease [26]. This finding was also matched with the study done in India stated that spirometric abnormality was more prevalent in 
symptomatic workers and there was an association between spirometry results and respiratory symptoms in cotton mill workers [29]. This might be due to increased dust exposure in the working environment and the accumulation of dust in the respiratory system. Dust particles or dust-containing macrophages causing injury to the lungs, and then fibrous lung tissue provided functional impairment.

The spirometric data of the current study showed a significant reduction of lung functions that occurred in most textile workers who were exposed to increased respirable dust concentration. It was consistent with the finding of the Taiwan study reported that more prevalence of impaired lung functions occurred in the cotton textile workers with higher exposure to dust [8]. This finding also supported to the results of the study done in Pakistan showed that mean dust exposure level affects on lung functions of textile workers, and increased dust concentration led to more decline in lung functions of textile workers [30]. This consistent finding provided strong evidence of increased respirable dust exposure that was an associated factor of reduced lung functions.

The smoking habit was not associated with lung functions in this study resulting from a low distribution of workers with smoking history. The results of this study might be generalized to elsewhere in which the workers are involved in the same occupational setting. However, the results might be varied depending on the diversity of basic characteristics, risk behaviors, respirable dust exposure, and implementation of occupational safety measures. There were some limitations to this study. The first was related to healthy worker effect which means that the workers who developed the respiratory symptoms may have quitted the job. Airborne endotoxin is more responsible for occupational respiratory diseases than respiratory dust itself and so, lack of the measurement of endotoxin exposure in the workplace was the second limitation of this study. Thirdly, the crosssectional study could not determine the cause and effect relationship and therefore it would require further prospective studies in order to assess the causality and confirm the findings of this study. Finally, the interview by using the questionnaire method was another limitation because it may cause recall bias and interviewer bias. Despite all of these limitations, this study might be a reasonable source of information for occupational health and safety.

\section{Conclusions}

The respirable dust concentration was the highest in the twisting department of the weaving section. The textile workers involved in the twisting department, those who were more than 5 years of service duration, and those who had increased respirable dust exposure were at risk for reduced lung functions. A total enclosure of the early stages of cotton processing and ventilation system that keeps the enclosure under negative pressure is needed to reduce respirable dust exposure. The industry administration should arrange the safety and health training regarding potential health effects of respirable dust exposure, preventive measures in the workplace, good work practices, performance assessment and workplace environment measures. The employers should explore the engineering control measure, occupational safety policies, and administrative controls to reduce respirable dust exposure. Additionally, periodically assessment of lung functions with spirometry should be applied to textile workers for screening the occupational lung diseases. The government should provide the funding or technical support to textile industries for the installation of new technologies and make the law and policies for checking the level of dust concentration daily or weekly in basis.

\section{Abbreviations}

$\mathrm{Cl}$ : Confident Interval; FEV ${ }_{1}$ : Forced Expiratory Volume in the First Second; FVC: Forced Vital Capacity; OR: Odd Ratio; SD: Standard Deviation

\section{Supplementary Information}

The online version contains supplementary material available at https://doi. org/10.1186/s12889-021-10712-0.

Additional file 1. English language version of the questionnaire.

\section{Acknowledgments}

We would like to acknowledge all the study participants from the textile mill for their commitment in this study. We sincerely thank Dr. Than Htut (Honorary Professor), Department of Occupational and Environmental Health, University of Public Health, Yangon for his advice and comments. We are also thankful to Dr. Kay Khine Aye (Deputy Director), Daw San San Lwin and Daw Po Po Chit (Hygiene Officers), and U Toe Maung (Township Health Nurse) from the Occupational and Environmental Health Division,

Department of Public Health, Ministry of Health and Sports for provision of technical advice and supports. We would like to express our thanks to Daw Myint Aye, Factory Manager of the textile mill (Thamine) for permission to collect the data.

\section{Authors' contributions}

TWO, MTD, YMH and ZMH conceptualized the study, and contributed to design and research question development. TWO and YMH performed data collection. TWO, PPS and KMT carried out data analysis and interpretation of the results. TWO, MTD, TZL, YMH and ZMH contributed to final revision of manuscript for important intellectual content. All authors read and approved the final manuscript.

\section{Funding}

This study received no specific grant from any funding agency in the public, commercial, or not-for-profit sectors.

Availability of data and materials

The data analyzed for this manuscript are available from the corresponding author and can be made accessible upon reasonable request.

\section{Declarations}

Ethics approval and consent to participate

The Ethical Committee, Defence Services Medical Academy, Yangon Region, Myanmar approved data collection and written informed consent before the study commences. The permission to collect the data was also approved by 
authorities of textile mill (Thamine), Yangon Region, Myanmar. The survey information sheet including the study objectives, contents of questionnaires, measurement procedure and rights of participants were explained to the participants before conducting interviews. The written informed consents signed by all participants were obtained. All ethical requirements stringently ensured to keep participants confidentiality.

\section{Consent for publication}

Not applicable.

\section{Competing interests}

The authors declare that they have no competing interests.

\section{Author details}

${ }^{1}$ Special Operation Medical Research Department, Defence Services Medical Research Centre, Nay Pyi Taw, Myanmar. ${ }^{2}$ Department of Environmental and Occupational Health, University of Public Health, Yangon, Myanmar. ${ }^{3}$ Department of Prevention and Research Development of Hepatitis, AIDS and Other Viral Diseases, Health and Disease Control Unit, Nay Pyi Taw, Myanmar. ${ }^{4}$ Department of Preventive and Social Medicine, University of Medicine, Mandalay, Myanmar. ${ }^{5}$ Department of Preventive and Social Medicine, Defence Services Medical Academy, Yangon, Myanmar. ${ }^{6}$ Defence Services Liver Hospital, Yangon, Myanmar.

\section{Received: 29 September 2020 Accepted: 25 March 2021} Published online: 07 April 2021

\section{References}

1. Takahashi K, Sekikawa A, LaPorte R, Satoh T, Pan G, Ren A, et al. Occupational lung diseases and global occupational health on the net. Occup Med. 1998;48(1):3-6. https://doi.org/10.1093/occmed/48.1.3.

2. World Health Organization. Occupational health: a manual for primary health care workers: Regional Office for the Eastern Mediterranean, World Health Organization; 2002. 165 p.

3. Mehwish N, Mustafa U. Impact of dust pollution on worker s health in textile industry: a case study of Faisalabad, Pakistan. Islamabad: Pakistan Institute of Development Economics; 2016. p. 19.

4. World Health Organization. Hazard prevention and control in the work environment: Airborne dust: Department of Protection of the Human Environment, World Health Organization; 1999. 2-6 p.

5. Sangeetha B, Rajeswari M, Atharsha S, Saranyaa K, Ramya S. Cotton dust level in textile industries and its impact on human. Int J Sci Res Publ. 2013; 3(4):1-6.

6. Daba Wami S, Chercos DH, Dessie A, Gizaw Z, Getachew A, Hambisa T, et al. Cotton dust exposure and self-reported respiratory symptoms among textile factory workers in Northwest Ethiopia: a comparative cross-sectional study. J Occup Med Toxicol. 2018;13(1):13. https://doi.org/10.1186/s12995-01 8-0194-9.

7. Kilburn KH. Byssinosis and other diseases of textile workers. Environmental and occupational medicine. 3rd ed. Philadelphia: Lippincott-Raven Publishers; 1998. p. 449-55.

8. Su Y-M, Su J-R, Sheu J-Y, Loh C-H, Liou S-H. Additive effect of smoking and cotton dust exposure on respiratory symptoms and pulmonary function of cotton textile workers. Ind Health. 2003;41(2):109-15. https://doi.org/10.24 86/indhealth.41.109.

9. Wang XR, Pan LD, Zhang HX, Sun BX, Dai HL, Christiani DC. A longitudinal observation of early pulmonary responses to cotton dust. Occup Environ Med. 2003;60(2):115-21. https://doi.org/10.1136/oem.60.2.115.

10. Phakthongsuk P, Sangsupawanich P, Musigsan A, Thammakumpee G. Workrelated respiratory symptoms among cotton-fabric sewing workers. Int J Occup Med Environ Health. 2007;20(1):17-24.

11. Hinson AV, Lokossou VK, Schlünssen V, Agodokpessi G, Sigsgaard T, Fayomi B. Cotton dust exposure and respiratory disorders among textile Workers at a Textile Company in the southern part of Benin. Int J Environ Res Public Health. 2016;13(9):895. https://doi.org/10.3390/ijerph13090895.

12. Anyfantis ID, Rachiotis G, Hadjichristodoulou C, Gourgoulianis KI. Respiratory symptoms and lung function among Greek cotton industry workers: a cross-sectional study. Int J Occup Environ Med. 2017;8(1):32-8. https://doi. org/10.15171/ijoem.2017.888.

13. Tageldin MA, Gomaa AA, Hegazy EAM. Respiratory symptoms and pulmonary function among cotton textile workers at Misr company for spinning and weaving EL-Mahalla. Egypt Egypt J Chest Dis Tuberc. 2017; 66(2):369-76. https://doi.org/10.1016/j.ejcdt.2017.03.004.

14. Rylander R. Health effects of cotton dust exposures. Am J Ind Med. 1990; 17(1):39-45. https://doi.org/10.1002/ajim.4700170108.

15. Rom WN, Markowitz SB. Environmental and occupational medicine: Lippincott Williams \& Wilkins; 2007.

16. Christiani DC, Wang X-R, Pan L-D, Zhang H-X, Sun B-X, Dai H, et al. Longitudinal changes in pulmonary function and respiratory symptoms in cotton textile workers. Am J Respir Crit Care Med. 2001;163(4):847-53. https://doi.org/10.1164/ajrccm.163.4.2006063.

17. Tetemke D, Alemu K, Tefera Y, Sharma HR, Worku W. Knowledge and practices regarding safety information among textile workers in Adwa town, Ethiopia. Sci Postprint. 2014;1:1

18. Alli BO. Fundamental principles of occupational health and safety second edition. 2nd ed. Geneva: International Labour Organization; 2008. p. 2-8.

19. Ali NA, Nafees AA, Fatmi Z, Azam SI. Dose-response of cotton dust exposure with lung function among textile workers: MultiTex study in Karachi, Pakistan. Int J Occup Environ Med. 2018;9(3):120-8. https://doi.org/10.15171/ijoem.2018.1191.

20. Samet JM. A historical and epidemiologic perspective on respiratory symptoms questionnaires. Am J Epidemiol. 1978;108(6):435-46. https://doi. org/10.1093/oxfordjournals.aje.a112642.

21. The National Institute for Occupational Safety and Health. Occupational Exposure Limits, Flavorings-related Lung Disease: National Institute for Occupational Safety and Health, Centers for Disease Control and Prevention; 2018. https://uww.cdc. gov/niosh/topics/flavorings/limits.html. Accessed 28 June 2018.

22. Sim YS, Lee J-H, Lee W-Y, Suh DI, Oh Y-M, Yoon J-S, et al. Spirometry and bronchodilator test. Tuberc Respir Dis (Seoul). 2017;80(2):105-12. https://doi. org/10.4046/trd.2017.80.2.105.

23. Ranu H, Wilde M, Madden B. Pulmonary function tests. Ulster Med J. 2011; 80(2):84-90.

24. Silpasuwan P, Prayomyong S, Sujitrat D, Suwan-Ampai P. Cotton dust exposure and resulting respiratory disorders among home-based garment workers. Workplace Health Saf. 2016;64(3):95-102. https:/doi.org/10.1177/2165079915607495.

25. Alemu K, Kumie A, Davey G. Byssinosis and other respiratory symptoms among factory workers in Akaki textile factory, Ethiopia. Ethiop J Health Dev. 2010;24:2.

26. Nagoda M, Okpapi J, Babashani M. Assessment of respiratory symptoms and lung function among textile workers at Kano textile Mills, Kano, Nigeria. Niger J Clin Pract. 2012;15(4):373-9. https://doi.org/10.4103/1119-3077.104505.

27. Ajeet S, Aniruddha D, Meenal K, Jaydeep N, Abhay M. To study the prevalence of chronic respiratory morbidities and related epidemiological factors among spinning mill workers. Glob J Health Sci. 2010;2(2):111.

28. Kumie A, Bråtveit M, Deressa W, Wakuma S, Moen BE. Personal cotton dust exposure in spinning and weaving sections of a textile factory, north Ethiopia. Ethiop J Health Dev. 2020;34:2.

29. Dangi BM, Bhise AR. Cotton dust exposure: analysis of pulmonary function and respiratory symptoms. Lung India. 2017;34(2):144-9. https://doi.org/1 0.4103/0970-2113.201319.

30. Snashall D, Patel D. ABC of occupational and environmental medicine. 3rd ed: Wiley; 2012. p. 75-8.

31. Tefera $Y$, Schlünssen $V$, Kumie A, Deressa W, Moen BE, Bråtveit M. Personal inhalable dust and endotoxin exposure among workers in an integrated textile factory. Arch Environ Occup Health. 2020:1-7.

32. Mberikunashe J, Banda S, Chadambuka A, Gombe NT, Shambira G, Tshimanga $M$, et al. Prevalence and risk factors for obstructive respiratory conditions among textile industry workers in Zimbabwe, 2006. Pan Afr Med J. 2010;6:1.

33. Aminian O, Mozafari SAR, Haghighi KS, Chavoshi F, Saraie M, Izadi N. Study of respiratory symptoms and pulmonary function in cotton textile workers. J Basic Appl Sci Res. 2013;3(4):33-6.

34. Ozkurt S, Kargi BA, Kavas M, Evyapan F, Kiter G, Baser S. Respiratory symptoms and pulmonary functions of workers employed in Turkish textile dyeing factories. Int J Environ Res Public Health. 2012;9(4):1068-76. https:// doi.org/10.3390/ijerph9041068.

35. Tefera Zele Y, Kumie A, Deressa W, Moen BE, Bråtveit M. Reduced cross-shift lung function and respiratory symptoms among integrated textile factory Workers in Ethiopia. Int J Environ Res Public Health. 2020;17(8):2741. https:// doi.org/10.3390/ijerph17082741.

\section{Publisher's Note}

Springer Nature remains neutral with regard to jurisdictional claims in published maps and institutional affiliations. 